\title{
Lake Bourget regional erosion patterns reconstruction reveals Holocene NW European Alps soil evolution and paleohydrology
}

\author{
Fabien Arnaud ${ }^{a,{ }^{*}}$, Sidonie Révillon ${ }^{b}$, Maxime Debret ${ }^{c}$, Marie Revel $^{\mathrm{d}}$, Emmanuel Chapron ${ }^{\mathrm{e}}$, \\ Jérémy Jacob $^{e}$, Charline Giguet-Covex ${ }^{a}$, Jérôme Poulenard ${ }^{a}$, Michel Magny ${ }^{f}$
}

\author{
a Environnement, Dynamique et Territoires de Montagne (EDYTEM), Université de Savoie, CNRS, 73373 Le \\ Bourget du Lac, France \\ ${ }^{\mathrm{b}}$ Géosciences Marines, IFREMER, 29280 Plouzané, France \\ c Laboratoire de Météorologie Dynamique \& CERES-ERTI (IPSL), Ecole Normale Supérieure, 75231 Paris, \\ France \\ ${ }^{\mathrm{d}}$ Géosciences Azur, Université de Nice, CNRS, 06000 Nice, France \\ Institut des Sciences de la Terre d'Orléans, Université d'Orléans, CNRS, 45000 Orléans, France \\ f Laboratoire Chronoenvironnement, Université de Franche-Comté, CNRS, 25000 Besançon, France \\ *: Corresponding author : Fabien Arnaud, email address : fabien.arnaud@univ-savoie.fr
}

\begin{abstract}
:
Two well-dated ca Holocene-long sedimentary sequences from deepest parts of Lake Bourget provide new insights onto the evolution of erosion patterns at a regional scale in NW European Alps. The combination of high resolution geochemistry - XRF core scanning, calibrated by 150 punctual measurements - and isotope geochemistry $(\varepsilon N d)$ of the terrigenous fraction permitted the reconstruction not only of the intensity, but also the type (physical erosion vs. chemical weathering) and the location (Prealpine massifs vs. High Crystalline massifs) of dominant erosion processes. Those data point the persistency of weak erosion fluxes from 9600 to 5500 cal. BP due both to a dry climate and the growing sheltering effect of soils that rapidly progressed between 9600 and $8000 \mathrm{cal}$. BP. Soils then reached a steady state before being destabilised around $4400 \mathrm{cal}$. BP, probably in response to human impact. The human impact then reached a sufficient intensity to change erosion patterns at a regional scale, but did not result in a significant increase of the regional terrigenous flux. The following enhancement of erosion processes occurred around $2700 \mathrm{cal}$. BP. It was first paced by changing climatic conditions, but probably reinforced by human impact during Late Iron Age - Antiquity period. Over the long-term trend, the Lake Bourget record pinpoints an evolution of paleohydrological conditions in the Alps dominated by dry conditions from 9500 to 4400 cal. BP and a subsequent drift toward wetter conditions that culminated during the so-called Little Ice Age (ca 1350-1900 AD). In such a context the current dry conditions in European Alps appear out-of-trend. At high resolution, 17 periods of enhanced hydrological activity highlight the rapid climatic changes that are typical of the Holocene.
\end{abstract}




\section{Graphical abstract :}

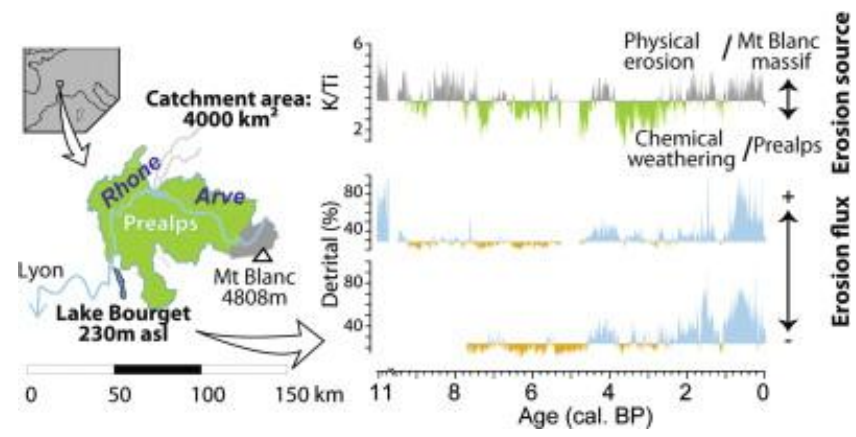

\section{Highlights}

A continuous regional (surface area $>4000 \mathrm{~km}^{2}$ ) sequence of Holocene erosion. Elemental and isotope geochemistry tracks provenance source and erosion patterns. Early- to mid-Holocene: low erosion rates; Neoglacial: enhanced physical erosion. Human impact detected at Bronze Age, Gallo-Roman and Medieval periods. Climate seems the main driver of erosion increase in Late Holocene.

Keywords : Holocene ; Ips ; Erosion ; Soil dynamics ; Paleohydrology 


\section{Introduction}

In contrast to huge temperature shifts that characterised glacial periods, Holocence climate variability is subtle and dominated by changes in moisture distribution (Mayewski et al., 2004; Magny et al., 2011). Consequently, it is crucial to be able to reconstruct past hydrological patterns in order to understand past and future consequences of climate changes. Reconstructing erosion fluxes from sediment archives could help reaching this goal, providing the hypothesis that terrigenous input depends principally on the hydrological activity is completed. In the European Alps, such an approach has been applied in large lakes Constance (Wessels, 1998) and Bourget (Arnaud et al., 2005; Chapron et al., 2005; Debret et al., 2010) in order to get a region-wide representative signal that covers most of the Holocene. However the used proxies did not allow to fully discuss processes that link climate and erosion. In particular, very few is known about the role of soil evolution, including human land-use, upon terrigenous fluxes at a regional scale in the Alps. We attempt to address this question by reconstructing erosion patterns through a detailed high resolution geochemical study of two cores taken in Lake Bourget, at different locations on the track of River Rhône incoming sediment flux.

Most of the Rhône-drained Lake Bourget catchments area is made of Mesozoic sedimentary units. However it also includes the Mont Blanc Massif that is made of crystalline rocks. Those parts of the catchment differ also by their geomorphology, only the Mont Massif hosting high elevation glaciers. As a consequence, only the first one is suitable for soil development and downstream human activities which may influence erosion patterns. At the opposite, glaciers are by far the main erosion agent in the Mont Blanc Massif which hence depends only on climate conditions. We took advantage of this bipartition to investigate the respective roles of soil dynamics - including natural and anthropogenic processes - and climate forcing upon erosion patterns. We use major elements concentrations and neodymium isotope compositions, in attempt to track the intensity of silicate flux (total terrigenous abundance) as well as both its provenance source $(\varepsilon \mathrm{Nd})$ and degree of weathering $(\mathrm{K} / \mathrm{Ti}$ ratio and Chemical Index of Alteration - CIA).

Based on these new data, we attempt to address the controversial question of the potential impact of human activity on erosion patterns (Dearing \& Jones, 2003, Piccarreta et al., 2011). Taking account this potential disturbance of the signal, we finally investigate the relationship between the evolution of terrigenous fluxes and paleohydrological conditions over NW European Alps.

\section{Studied site and sediment sequences}

Lake Bourget is the largest natural lake in France. Its sediment cover was investigated for more than a decade through several geophysics (Chapron, 1999; Chapron et al., 1999; van Rensbergen et al., 1999; Chapron et al., 2005; Ledoux et al., 2010) and coring surveys, both in deep water (Chapron et al., 1999; 2002; 2005; Arnaud et al., 2004; 2005; Arnaud, 2005; Revel-Rolland et al., 2005; Jacob et al., 2008; 2009; Jung et al., 2008; Debret et al., 2010; Millet et al., 2010; Giguet-Covex et al., 2010) and 
from shallower sites (Magny and Richard, 1985; Magny et al., 2009). It also hosts several archaeological lake dwelling sites spanning from the Neolithic to the Middle Age which are currently underwater (Marguet, 2000). Although the lake is fed by three main tributaries, the present study focuses on the northern sub-basin where the terrigenous fraction is today mainly supplied by the River Rhône (Fig. 1; Revel-Rolland et al., 2005).

River Rhône is the current lake emissary through its natural outlet, but this situation is inverted during major floods when the sediment-loaded waters from the river Rhône enter the lake. As the particulate sediment load from the Swiss alpine Rhône is totally trapped in Lake Geneva (Bravard, 1987), sedimentation in Lake Bourget have recorded the hydrological activity of the French part of the alpine Rhône. Main River Rhône tributaries are here the Arve River (1980 km² watershed) notably draining the glacier-covered Mont Blanc range and the Fier River (1330 $\mathrm{km}^{2}$ watershed), draining the subalpine Aravis and Bauges massifs. The total River Rhône sediment-supplying catchments area when it enters Lake Bourget is about $4000 \mathrm{~km}^{2}$.

The situation of intermittent entering of Rhône River into Lake Bourget has not always prevailed. Indeed, stratigaphic and seismic investigations showed that during the Lateglacial, the ombilic currently occupied by the Lavours and Chautagne swamps (Fig. 1) was entirely occupied by the river Rhône floodplain (Nicoud et al., 1987; Chapron, 1999; Van Rensebergen et al., 1999). By that time river Rhône was directly inflowing Lake Bourget as it is marked by the development of an important delta on the northern end of the Lake (Van Rensebergen et al., 1999). Subsequently, following a period of sediment accumulation within the ombilic, river Rhône auto-captured itself within its own incised sediment and left Lake Bourget on its left flank. Very few is known about the modalities and timing of this auto-capture. However, we know this permitted the development of peat accumulation in Lavours and Chautagne backswamps, on the right and left flanks of the new Rhône course, respectively. $\mathrm{A}{ }^{14} \mathrm{C}$ age, at the bottom of a core taken in Chautagne swamp dates the onset of peaty accumulation, and downstream, the abandonment of the lake by the river $8940 \pm 45 \mathrm{BP}(10,060 \pm 150$ cal. BP; Disnar et al., 2008). This date marks the onset of the Holocene drape that characterises the Holocene deposit in Lake Bourget (Chapron). It is made of fine-grained biogenic carbonate (mean size: $5 \mu \mathrm{m}$ ) more or less diluted by silty terrigenous input (mean size ca. $7 \mu \mathrm{m}$ ), including both carbonates and silicates (Arnaud et al., 2005; Arnaud, 2005; Revel-Rolland et al., 2005).

\subsection{Core LDB01-I}

Core LDB01-I ( $45^{\circ} 44.848^{\prime} \mathrm{N}$; $5^{\circ} 50.891^{\prime} \mathrm{E}, 128 \mathrm{~m}$ water-depth) was taken in 2001 , from a site submitted to distal river Rhône interflows (Fig. 2, Chapron et al., 2002) and was first described in Arnaud et al. (2005). Magnetic susceptibility (MS) was used as a marker of Rhône River detrital input over the last 7200 years (Arnaud et al., 2005). However, due to high carbonate contents, the insufficient precision of the MS signal in the lowermost part of the core precluded from a fine interpretation of this proxy between 2700 and $7200 \mathrm{cal}$. BP. We present here new results of major elements concentrations 
measured following a 5mm-step using an XRF core-scanner, as well as grain size and major element punctual measurements.

\subsection{Core LDB04-I}

Core LDB04-I ( $45^{\circ} 47 \mathrm{~N} ; 5^{\circ} 50 \mathrm{E}, 107 \mathrm{~m}$ water-depth) was taken in 2004 , by $107 \mathrm{~m}$ water depth in the northern sub-basin (Fig. 2). The same lithological units as in core LDB01-I (Arnaud et al., 2005) were recognised Debret et al. (2010). An additional darker and laminated unit is present (U3). Seismic stratigraphy indicates that $\mathrm{U} 3$ corresponds to a giant underwater slide. This slide affected sediments of the former Rhône delta when it was entering directly within Lake Bourget, i.e. prior to $c a .10 .5 \mathrm{ka}$ cal. BP. It seems the integrity of the sediment pile was conserved within the slided unit. However, in this paper, we will only consider them as representative of the sediment fraction "prior to the Rhône autocapture" and not as a continuous sedimentary sequence. Between depth 5.8 and 6.8m in LDB04-I sequence, i) an interbedded slump within the sediment series and ii) a sediment hiatus due to coring difficulties through this particular level (fluidised sediment) have been described (Debret et al., 2010).

\section{Analytical procedures}

\subsection{Grain size measurements}

Grain size measurements of the non-carbonated fraction were performed on a Malvern Mastersier 800 following the procedure by Trenteseaux et al. (2001), modified by Arnaud (2005). Forty nine and forty seven measurements were performed on LDB01-I and LDB04-I, respectively.

\subsection{Geochemistry}

High resolution geochemical logging was performed on an Avaatech core scanner at the Marum center in Bremen (Germany). Titanium and potassium results only are used in this paper. The chosen sampling steps were $5 \mathrm{~mm}$ and $10 \mathrm{~mm}$, for cores LDB01-I and LDB04-I, respectively, which correspond to an average time resolution of 5 and 10 years, respectively, according to previous chronological information.

Major element concentrations were measured on $1 \mathrm{~cm}$-tick discrete samples using X-Ray Fluorescence (XRF) at the University Claude Bernard of Lyon. The sampling step was about $10 \mathrm{~cm}$ and $20 \mathrm{~cm}$ (i.e., 98 and 49 samples) in cores LDB01-I and LDB04-I, respectively (Fig. 2).

Neodymium isotopic compositions were measured on selected samples. Each sample was sieved at $63 \mu \mathrm{m}$ and only the fraction $<63 \mu \mathrm{m}$ was retained for isotope composition analyses. Each sample was chemically treated to remove organic matter and carbonates in order to analyze only the siliciclastic components of the terrigenous material following the procedure described in Revel-Rolland et al., 2005. About $100 \mathrm{mg}$ of sample were weighted and dissolved in high pressure Teflon bombs in a mixture of $\mathrm{HF}, \mathrm{HNO}_{3}$ and $\mathrm{HClO}_{4}$ following the method described in Revillon and Hureau-Mazaudier, 
2009. Nd was chemically separated using Eichrom specific resins TRU-spec, and Ln-spec following usual procedures Pin and Santos Zalduegui, 1997.

Neodymium isotope compositions were measured in static mode on a Finnigan TRITON at the Pôle de Spectrométrie Océan (PSO, UBO/CNRS/IFREMER, Brest, France). Procedural blanks were $<300$ pg and therefore negligible in all cases. Nd isotope compositions of standard solutions La Jolla and JNdi gave ${ }^{143} \mathrm{Nd} /{ }^{144} \mathrm{Nd}=0.512852 \pm 0.000008(2 \sigma, \mathrm{n}=16)$ and ${ }^{143} \mathrm{Nd} /{ }^{144} \mathrm{Nd}=0.512101 \pm 0.000006(2 \sigma, \mathrm{n}=10)$ respectively. ${ }^{143} \mathrm{Nd} /{ }^{144} \mathrm{Nd}$ is normalized to ${ }^{146} \mathrm{Nd} /{ }^{144} \mathrm{Nd}=0.7219$. For convenience, $\mathrm{Nd}$ isotope results are expressed as: $\varepsilon_{\mathrm{Nd} 0}=\left[\left({ }^{143} \mathrm{Nd} /{ }^{144} \mathrm{Nd}_{\text {(meas) }} /{ }^{143} \mathrm{Nd} /{ }^{144} \mathrm{Nd}_{(\mathrm{CHUR})}\right)-1\right]^{*} 10^{4}$. The CHUR (Chondritic Uniform Reservoir) value is 0.512638 Jacobsen and Wasserburg, 1980.

\subsection{Chronology}

Both cores LDB01-I and LDB04-I were previously dated independently (Arnaud et al., 2005; Debret et al., 2010). However, we took advantage of their detailed litho-stratigraphic correlations to add cross-correlated ${ }^{14} \mathrm{C}$-dated samples from both of them (Table 1). We thus present a refined age-model for each of the studied cores. This was done by running the "CLAM" program (Blaauw, 2010) under the mathematics software "R" version 2.12.2 (R Development Core Team, 2011). The used calibration curve was Intcal09 (Reimer et al., 2009). All ages were acquired on vegetal terrestrial macroremains to avoid reservoir effect.

\section{Results and discussion}

\subsection{Downcore evolution of selected proxies}

Generally speaking, both results from core scanning as well as from punctual measurements, exhibit a strong covariation of all presented elements (Ti, K, Al, Na; Fig. 2). In first instance, this supports our assumption of a simple-mixing system made of two end-members presenting a constant geochemical composition, i.e. biogenic carbonate and river-borne silicates. However the evolution of the CIA index indicates second order changes of the major element composition in both cores.

The above statement of source constancy must be slightly nuanced in the case of LDB01-I. Indeed in some particular levels this core presents a slight excess in $\mathrm{Na}$ and $\mathrm{K}$ vs. Ti and $\mathrm{Al}$, as it is marked by low CIA values (Fig. 2). Remarkably, those particular levels also present enrichments in the noncarbonate sandy fraction. We thus interpret changes in CIA as the influence of a minor sandy fraction made of a mixture of quartz and although of feldspars, those ones presenting lower CIA indexes than the $<10 \mu \mathrm{m}$ silty-clays brought by River Rhône (Arnaud, 2005). As a consequence the CIA index will not be used as a proxy for Rhône terrigenous fraction composition in LDB01-I. 
Titanium content is commonly used as a proxy of terrigenous silicate input when interpreting XRF core scanner results as it is strictly of terrigenous origin, well-measured by this technique and is only weakly affected by weathering and underwater redox processes. However, it is a minor element, i.e. its concentration is usually $<1 \%$. It is hence more comprehensive to plot the total abundance of the terrigenous fraction to have a clearer image of the evolution of the ratio between allochthonous and autochthonous sedimentations. In that aim, we calculated the total terrigenous fraction abundance, assuming that, in each core, the maximum value of titanium concentration was corresponding to a total terrigenous fraction of $100 \%$ (Wessels, 1998). The maximum Ti content values taken into account were $0.51 \%$ and $0.58 \%$ in LDB01-I and LDB04-I, respectively. The total terrigenous contribution was then computed following:

(1a) Total terrigenous abundance $=\mathrm{TiO}_{2} / 0.51 \times 100$, in LDB01-1, and

(1b) Total terrigenous abundance $=\mathrm{TiO}_{2} / 0.58 \times 100$, in LDB04-1.

In addition to $\mathrm{Ti}$ and total terrigenous input, which track the quantity of matter brought by the river to the lakes, we used an index derived from the Chemical Index of Alteration (CIA), defined by Nesbitt and Young (1982) as:

(2) $\mathrm{CIA}=\mathrm{Al}_{2} \mathrm{O}_{3} /\left(\mathrm{Al}_{2} \mathrm{O}_{3}+\mathrm{CaO}+\mathrm{K}_{2} \mathrm{O}+\mathrm{Na}_{2} \mathrm{O}\right) \cdot 100$

In this study, we were not able to assess the $\mathrm{CaO}$ content of the silicate fraction; we thus slightly changed the equation into:

(3) $\mathrm{CIA}=\mathrm{Al}_{2} \mathrm{O}_{3} /\left(\mathrm{Al}_{2} \mathrm{O}_{3}+\mathrm{K}_{2} \mathrm{O}+\mathrm{Na}_{2} \mathrm{O}\right) \cdot 100$

We argue that this did not change considerably the results, as we only discuss about relative variations in CIA. When comparing our results with the CIA of other records or of pure mineral phases, one must however remember that our results are slightly over-estimated.

Non-weathered feldspars have CIA around 50 and granites: 45 to 55. At the opposite, clay minerals present higher values: from 70 for illite to 85 for smectite and up to 100 for kaolinite, following an increasing weathering gradient. The CIA index gives thus an assessment of the relative proportion of primary minerals vs. secondary ones. Hence, if the source remains constant it can be interpreted as a proxy for the intensity of chemical weathering.

The CIA index has been calculated for all punctual XRF measurements; however it was not possible to calculate it from core scanner results because of the poor definition of the aluminum signal. We hence use instead the $\mathrm{K} / \mathrm{Ti}$ ratio. Indeed $\mathrm{K}$ is more concentrated in non-weathered minerals, as it is preferentially leached by weathering processes. Plotting K/Ti vs. CIA index gave a high anticorrelation, with a R2 value of 0.8 and 0.85 for LDB04-I and LDB01-I samples, respectively (not shown). 
Isotopic composition of neodymium $(\varepsilon \mathrm{Nd})$ presents fluctuations along both cores, staying roughly within the range of measured samples from core B16 (-9.3 to -10.8; Revel-Rolland et al., 2005; cf. black boxes in Fig. 2). There is a certain relationship between terrigenous fraction abundance and $\varepsilon \mathrm{Nd}$ : in general, $\varepsilon \mathrm{Nd}$ are more negative when the abundance of the terrigenous fraction is low. However this technique being relatively time consuming, it was not possible to make as many measurements as for major elements. This results in a relatively lower resolution signal which is more difficult to compare with the other ones. For that reason, $\varepsilon N d$ will be sole proxy for which we will present graphs combining samples taken in different cores vs. a common age-scale. It will hence be easier to interpret its variations as a function of age.

The right part of Figure 2 presents the correlation between XRF measurements of Ti and $\mathrm{K}$ in both cores from both core scanning and punctual samples. The correlation appears to be satisfying for all presented elements except for K in LDB01-I. We will thus not use this last one in further development of this paper. In particular the induced bias precludes to accurately compute the $\mathrm{Ti} / \mathrm{K}$ ratio from core LDB01-I.

\subsection{Age-depth modelling}

Age-depth models were computed using a smooth spline function, with a smoothing factor of 0.1 (Blaauw, 2010) and reported in Figure 3. One age at 4.6m in LDB01-I (4.1m in LDB04-I) appeared to be slightly too old as it was generating age inversions in the model. It has thus been removed from the dataset and new models were generated. Sedimentation rates were automatically calculated and also displayed on Figure 3 (lower panel).

The age-depth model comprises both a hiatus and an instantaneous deposit at 6.2-6.75m-depth (Fig. 3 inset A). The age of the deposit has been fixed as the modelled age at $6.2 \mathrm{~m}(4870+/-150 \mathrm{cal}$. BP $)$. The time-cover of the coring-generated hiatus can be assessed by making the difference between the modelled age of the uppermost non-reworked sediment layer (i.e. $5220 \mathrm{cal}$. BP at $6.75 \mathrm{~m}$ ) and the age of the slump (4870 cal. BP): 350 years (i.e. ca. $40 \mathrm{~cm}$ ).

Following the same procedure, we imposed to the model both a hiatus and an instantaneous deposit between 11 and 10.2m (Fig. 3 inset). The maximum age of the instantaneous deposit (9900 cal. BP) is given by two similar ${ }^{14} \mathrm{C}$ ages $(8645+/-45$ and $8720+/-50 \mathrm{BP})$ present in it. We arbitrary fixed the age of instantaneous deposit as the maximum of probability of those ages (ca. $9700 \mathrm{cal}$. BP). The resulting hiatus covers the period $9700-10350$ cal. BP, i.e. ca. 650 years. 


\subsection{The Holocene evolution of regional erosion patterns at the Alpine footstep with respect to Alpine soils, vegetation and climate histories}

In a previous work, Debret et al. (2010) defined 12 periods of enhanced detrital input labelled by letters from A to L. The higher resolutioon of our proxies and the increased consistency given by the comparison of two cores led us to refine this cutting into 17 periods over the last 9600 years. We however kept Debret et al.es nomenclature, but slightly refined the limits of defined periods and, when useful, added five new ones in between the former ones (B1, C1, C2, K1, K2). Finally, we added the period $\mathrm{M}$ corresponding to the sediments of unit 3. Those short-term fluctuations are superimposed on the long-term evolution of the detrital input we describe below as periods I to VIII (Fig. 4).

\subsubsection{Period I: $11000-10500$ ka cal. BP}

The oldest sediments in core LDB04-I from the deep basin are dated ca. $11 \mathrm{ka}$ cal. BP. According to seismic imagery they are not in place (Debret et al., 2010). No sediment has been recovered dated between 10.5 and $9.6 \mathrm{ka}$ cal. BP. The transition from unit 3 to unit 2 marks the onset of the Holocene drape, i.e. the characteristic Holocene sedimentary facies of Lake Bourget (van Rensbergen et al., 1999).

The age-depth model within unit 3 (HDU) must be taken cautiously. We will thus not use results from this unit as a continuous record, but as representative, in average, of the very early Holocene period, when River Rhône was directly entering the lake (period M, Fig. 4). Sediments from this period present the highest values of terrigenous abundance and sedimentation rate $(3.8 \mathrm{~mm} / \mathrm{a})$, as well as of proxies of physical weathering (high $\mathrm{K} / \mathrm{Ti}$, low $\mathrm{CIA}$ ). This can be explained easily, considering the river Rhône was entering directly Lake Bourget.

The variability of computed terrigenous abundance (40 to $100 \%$ ), whereas the CIA (i.e. the composition of the siliciclastic fraction) remains almost constant, indicates that a significant biogenic carbonate production probably occurred. Interestingly, the $\varepsilon \mathrm{Nd}$ value is relatively low, whereas the CIA is low. This means the main source of erosion is made of perialpine sedimentary rocks (low $\varepsilon \mathrm{Nd}$ ) which were by that time only poorly weathered (low CIA), indicating the soil formation processes were still relatively weak.

\subsubsection{Period II: $9700-7400$ cal. BP}

The early Holocene is characterised by low sedimentation rates $(<1 \mathrm{~mm} / \mathrm{a})$ and a major contribution of biogenic carbonates ( 65 to $80 \%$ ), as a consequence of very low terrigenous input. However proxies for physical weathering (K/Ti, CIA), as well as $\varepsilon N d$ are still high, suggesting the predominance of physical erosion in Alpine catchments.

Within this period, some peaks in terrigenous abundance indicate periods of enhanced physical erosion around $9.4 ; 8.9 ; 8.6 ; 8.3,8.0$ and 7.6 ka cal. BP (periods L, K2, K1, K, J, I, respectively). Within age 
uncertainty, period J ( $8.3 \mathrm{ka}$ cal. BP) could correspond to the so-called $8.2 \mathrm{ka}$ event which has been demonstrated to be relatively wet in Lake Annecy, some kilometres west from Lake Bourget (Magny et al., 2003). However, one must note, it is not a prominent wiggle in detrital input, whereas the $8.2 \mathrm{k}$ event was marked by a dramatic drop in temperature at the footstep of the Alps (von Grafenstein et al., 1999).

Periods of enhanced terrigenous supplies are frequent, but relatively weak. The persistence of high $\mathrm{K} / \mathrm{Ti}$ ratio tracks the weakness of pedogenetic processes during this apparently dry, as indicated by low detrital input, period (9.6-7.8 ka cal. BP). The preponderance of physical erosion might reflect the necessary delay for the vegetation, and thus for soils, to recover from Lateglacial conditions. At $7.8 \mathrm{ka}$ cal. BP, a marked drop in $\mathrm{K} / \mathrm{Ti}$ tracks the increasing contribution of weathered material at the favour of a reduced terrigenous input. We interpret this signal as a marker of active soil formation in the Alpine catchments.

Those results are in agreement with recent results from a high altitude lake, within the catchments area of Lake Bourget. Indeed at Lake Anterne (2060 m asl), Giguet-Covex et al. (2011) showed that the period from 11 to $8 \mathrm{ka}$ cal. BP was dominated by physical erosion prior to a period of soil stabilisation. This last one was there evidenced by the deposit of more weathered material interpreted as the response to Alpine soils development (Giguet-Covex et al., 2011). It is noticeable that this period is also marked by the extension of trees up to the Subalpine belt (van der Knaap et al., 2005; David, 1993). The similarity of results from Anterne and Le Bourget suggests trees were developing in the uppermost parts of the catchments area, leading to the development of differentiated soils that modified the chemistry of eroded material carried by Rhône River floods.

\subsubsection{Period III: $7400-5700 \mathrm{cal} . \mathrm{BP}$}

This period is marked by low $\mathrm{K} / \mathrm{Ti}$ values, even in periods of relatively higher terrigenous input. We interpret this as the consequence of the soils development in the whole catchment area. This is in agreement with the growing idea that this period of the Holocene was marked by a pedological optimum during which developed soils occupied most of Alpine terranes, including high altitude ones, at least up to $2100 \mathrm{~m}$ asl (Mourier et al., 2010; Giguet-Covex et al., 2011).

Some peaks in terrigenous input mark periods of slightly enhanced erosion around 6.8 and $6 \mathrm{ka}$ cal. $\mathrm{BP}$ (periods $\mathrm{H}$ and $\mathrm{G}$ ). One notes that each rise in terrigenous input is accompanied by a rise in $\mathrm{K} / \mathrm{Ti}$, which may indicate a displacement of the sediment source toward the upper Arve catchment where physical erosion still prevails in the Mont Blanc massif. We however do not have $\mathrm{Nd}$ isotope compositions data in this period to further confirm this hypothesis.

\subsubsection{Period IV: $5700-3700$ cal. BP}

This period is made of two important rises in terrigenous supply at 5.7-5.4 and 4.8-3.8 ka cal. BP (periods $\mathrm{F}$ and $\mathrm{E}$ ), separated by an apparent pause in river discharge of about 600 years (5.4-4.8 ka cal. 
BP). The 4.8-3.8 ka cal. BP is the oldest, millennial-long period of enhanced terrigenous supply. It is characterised by some of the highest values of $\mathrm{K} / \mathrm{Ti}$, indicating the preponderance of physical erosion.

\subsubsection{Period V: 3700-2800 cal. BP}

At $3.7 \mathrm{ka}$ cal. BP, the $\mathrm{K} / \mathrm{Ti}$ signal marks a drastic drop, lasting ca. 1000 years. When compared to previous and following ones, even phases of enhanced detrital supplies from this period present significantly lower $\mathrm{K} / \mathrm{Ti}$. This must be interpreted as the preponderant erosion of well-developed soil horizons. Low values of $\varepsilon \mathrm{Nd}$ support this interpretation, suggesting the preponderance of Prealps erosion sources.

By that time Lake Anterne catchment experienced a strong intensification of erosive processes that has been attributed to human impact (Giguet-Covex et al., 2011) whereas in Austrian Alps Schmidt et al., 2002 also report the onset of human impact on erosive fluxes. In Lake Bourget geochemical record, this period does not correspond to a marked rise in terrigenous supply. The intense erosion triggered by human impact on highest catchment areas thus did not generate an excess in terrigenous supply down to the Rhône valley. However it is characterised by the lowest $\mathrm{K} / \mathrm{Ti}$ ratio of the whole sequence, even during periods of enhanced terrigneous input indicating the deposition of highly weathered material.

Based on the study of cores LDB04-I and LDB01-I, Jabob et al. (2008; 2009) demonstrated the synchronous occurrence of two biomarkers: miliacin (olean-18-en-3b-ol methyl ether) and TTHC (3,3,7-trimethyl-1,2,3,4-tetrahydrocrysene) at $3.7 \mathrm{ka}$ cal. BP. Those markers track the introduction of the non-native cultivated cereal Broomcorn millet (Panicum miliaceum) and a dramatic increase in uppermost soils erosion, respectively. Such a result was interpreted as a major shift in agricultural practises and land-use (Jacob et al., 2009). It occurred at a period when the terrigenous input was very low and is synchronous with very low $\mathrm{K} / \mathrm{Ti}$ values. Once again, this suggests that Bronze human impact on soil stability is detectable qualitatively as it changed the nature of the erosion products, but did not have a significant impact on regional terrigenous fluxes as they are recorded in Lake Bourget.

\subsubsection{Period VI: $2800-1600$ cal. BP}

Phase C2 (2.8-2.6 ka cal. BP) marks the onset of a rising trend in terrigenous input which is characteristic of the Late Holocene period and will end only within the mid- $20^{\text {th }}$ century AD. The terrigenous input significantly increases four times within only 1000 years (periods C2, C1, C and B1; at $2.8,2.4,2.2,1.9 \mathrm{ka}$ cal. BP, respectively). Each of those peaks presents a weaker chemical weathering contribution than the previous one, which can be interpreted as a diminishing contribution of low to mid-altitude non-glaciated catchments. However the $\varepsilon \mathrm{Nd}$ remains relatively low, indicating the constancy of the sediments source area. We thus interpret this period as marked by a reinforcement of the physical erosion in subalpine rather than high alpine catchments areas. 
Remarkably the increase in terrigenous contribution between 2.8 and $1.6 \mathrm{ka}$ cal. BP is more marked in core LDB01-I than at LDB04-I site. The different response of both sites indicates the preponderance during that period of interflows i.e. floods of lower magnitude. This could indicate that changes in both quantity and quality of terrigenous fluxes are driven rather by changes in erosion patterns than by enhanced precipitations. This is particularly true for the Roman Period which is known as a period of glacier retreat (Holzhauser et al., 2005; Joerin et al., 2006; 2008) and however presents higher detrital fluxes in our record. In Lake Anterne, this period is marked by the only phase of enhanced erosion which is in contradiction with climate record over the last 3500 years. This has been attributed to human impact (Giguet-Covex et al., 2012; David, 2010). It is hence possible that changes in land-use practices at the end of the Iron Age and during the Antique period produce a dramatic increase of erosion in Alpine catchments areas that was strong enough to be imprinted at a regional scale in Lake Bourget sediment record. However it is obvious that this period presents a really complex human climate - erosion pattern and requires deeper studies to be fully understood.

\subsubsection{Period VII: $1650-50$ cal. BP}

In LDB01-I, at $1.65 \mathrm{ka}$ cal. BP, both the sedimentation rate and the terrigenous supply experience a dramatic rise (1650-1300 cal. BP, i.e., 300-650 AD). However, in LDB04-I, the same period appears more contrasted and can be cut into two distinct phases: B1 (1650-1450 cal. BP, i.e. 300-500 AD) and B (1450-1300 cal. BP, i.e., 500-650 AD). During phase B1, the terrigenous input is high, but lower than in LDB01-I and moreover the K/Ti ratio remains low. During phase B (500-650 AD), the terrigenous input is even higher and $\mathrm{K} / \mathrm{Ti}$ reaches some of its highest values in the whole record. Moreover during B1 the $\varepsilon N d$ reaches an unprecedented value since the Early Holocene, indicating a massive influx of terrigenous particles from the Mt Blanc massif. As a consequence we interpret B1 (300-500 AD) as a period of enhanced erosion mainly in the lowest catchment area, characterised by low magnitude floods. By contrast, phase B (500-650 AD) is marked by an increasing contribution of the highest catchment area to the terrigenous flux and is interpreted as period of generalised more intense physical erosion. This phasing can be interpreted as a period dominated by human impact at the end of Antiquity (B1), whereas the High Middle Age (B) erosion patterns are dominated by a climate change, as indicated by a major glacier advance (Holzhauser et al., 2005).

The following period, between phases B and A (1300-1050 cal. BP, i.e., 650-900 AD) is marked by a drastic drop in terrigenous input and in $\mathrm{K} / \mathrm{Ti}$, reflecting the reduced influence of the highest catchment areas. The detrital supply rises then gradually until the onset of phase A around 750 cal. BP (1200 AD) and reaches a maximum around $650 \mathrm{cal}$. BP $(1300 \mathrm{AD})$. This progressive rise is punctuated by two short-lived peaks in detritism around 1050 (A2) and 900 (A1) cal. BP (i.e. 900 and 1050 AD, respectively). 
The terrigenous flux stays then high until the $20^{\text {th }}$ century AD. This is the longest, most prominent period of erosion throughout our continuous record (since $9600 \mathrm{cal}$. BP). It is dominated by the input of lowly weathered material (high $\mathrm{K} / \mathrm{Ti}$ ). The $\varepsilon \mathrm{Nd}$ has been measured following a relatively higher resolution and presents a strong variability, following variations in detrital input. The Mont Blanc source is hence well-imprinted, but this period of strong erosionnal activity concerns the whole catchment, as shown by the return to relatively low $\varepsilon N d$ during short-lived phases of relative drop in terrigenous supply.

Based on historical evidences, the second half of the Middle Age (800-1500 AD) has been a period of forest clearance in the Alps, especially between 1000 and 1350 AD (cf. Carrier and Mouthon, 2010, for an Alpine-wide review), this could explain the progressive rise in terrigenous regional flux. However, one must also notice that each periods A2, A1 as well as the onset of A corresponds to a marked advance of the Great Aletsch glacier (Holzhauser et al., 2005) as well as marked higher lake level in the neighbouring Jura massif (Magny et al., 2010). It is hence possible that glacier advances that preceded the onset of the LIA sensu stricto and moreover the one of the LIA itself completely hided the effects of human impact, as the glacial erosion was dominating the regional erosion flux. Of course this does not rule out the possibility that locally the human-steered land management led to important reinforcement of erosion processes. This point is however still a research field to be addressed.

\subsubsection{Period VIII: The $20^{\text {th }}$ century AD}

Since the early $20^{\text {th }}$ century AD, the terrigenous input experienced a drastic drop, linked to the end of the LIA. This decline coincides with a drop in $\mathrm{K} / \mathrm{Ti}$ and $\varepsilon \mathrm{Nd}$, marking a diminution in the contribution of high altitude material.

\subsection{Regional paleohydrological context}

In a recently published synthetic work Magny et al. (2011) pointed the importance of the long-term Holocene trend in precipitation patterns, in response to orbital forcing. Two of the main series used in Magny et al. (2011), lakes Accesa (Italy, Tuscany) and Cerin (Jura massif, 20km west of Lake Bourget), are reported together with Lake Bourget results on Fig. 4,. Additionally we present in this figure results from Lake Constance (Wessels, 1998) which is a system comparable to Lake Bourget. Wessels (1998) reconstructed past interflow activity from the mid-resolution measurement of major elements concentrations. Here we present the authigenic calcium carbonate concentration, on an inverted axis, as a proxy of Rhine river terrigenous input to Lake Constance. To facilitate the comparison of different records, we reported our 18 phases of enhanced terrigenous input represented as their average terrigenous input value (upper limit of shaded boxes) and have drawn the envelope of those values. 


\subsubsection{Long-term trend}

Obviously, all different records present the same long-term evolution. The early Holocene is marked both by high lake levels and maximum terrigenous supply. The strong decline in terrigenous supply in Lake Bourget between 10.5 and $9.6 \mathrm{ka}$ cal. BP is also marked in lake level records. However, it is first due to a major shift in sediment input pattern following the abandonment of the lake by River Rhône. It is remarkable that this river autro-capture was contemporaneous of a regional drop in lake levels. It can therefore be suggested that this change in local geomorphology is related to a climatic shift toward dryer conditions, leading to the incision of River Rhône bed.

The first post-abandonment peak in terrigenous flux (period L, $9.4 \mathrm{ka}$ cal. BP) is well correlated to a phase of high lake levels. The magnitude of this phase will not have an equivalent in lake level or in detrital supply before $4.4 \mathrm{ka}$ cal. BP. Indeed, the period $9.4-4.4 \mathrm{ka}$ cal. BP is the one of lowest hydrological activity of the whole Holocene. One marked exception must however be noticed around $5.5 \mathrm{ka}$ cal. BP, a date which marks in the Alps the onset of the so-called "Neoglacial" period (Magny et al., 2006; Deline and Orombelli, 2005). The 4.4-3.8 ka cal. BP event marks the onset of more humid conditions resulting both in a marked rise in lake levels and terrigenous input. It is contemporaneous of the so-called $4.2 \mathrm{ka}$ event that is marked regionally by more humid conditions (Magny et al., 2011) and locally by a marked rise in lake level (Magny et al., in press). The trend which is then initiated will culminate during the LIA and will only end at the $20^{\text {th }}$ century AD.

We thus confirm the Early and Mid Holocene (9.4-4.4 ka cal. BP) were dry period in NW Alps as well as in the Jura Mountains. On the contrary, the maximum of terrigenous supply during the LIA, but also during the so-called "Dark Age" period (ca. 400-700 AD) is well-associated with a marked rise in lake levels and can thus be interpreted as climatically-forced.

The continuity of our record over the last 9600 years, suggests that the first half part of this period (9600-4600 cal. BP) has been in average, dryer than the $20^{\text {th }}$ century AD. It also suggests that current climatic conditions, marked by low hydrological activity are out-of-trend compared to the Holocene long-term trend toward more humid conditions in NW Alps. Indeed despite a shot period of low terrigenous input during Medieval Warm Period, current conditions were not experienced since the Late Bronze Age driest period.

\subsubsection{Centennial-scale hydrological fluctuations}

Most of rises in lake levels evidenced in Accesa and Cerin lakes are well-marked in Lake Bourget. Slight discrepancies can occur, but most of them can be explained by different sampling resolutions and/or age-model model uncertainties (cf. correlation lines in Fig. 5). This points out the strong reactivity of Lake Bourget record to changing hydrological conditions, even at an infra-centennial scale. 
A main discrepancy must however be noticed for the period $5.3-4.7 \mathrm{ka}$ cal. BP when two marked rises in lake level are reported both in Cerin and Accesa lakes. Considering Lake Cerin is very close to Lake Bourget, one may not evocate a different climate pattern. However, this period corresponds to important reorganisations of Lake Bourget sedimentation patterns, as it is marked by the occurrence of an important slump deposit. It is hence possible that either the threshold to generate the inversion of flux from the Rhône to the lake was higher or the flood regime was dominated by underflows which have not been recorded in LDB01-I (interflows-dominated) and were not recovered in LDB04-I (missing section). Anyway this question remains open and will require further studies to be solved.

The strong correlation of lakes Constance and Bourget peaks in terrigenous between 5 and $2.2 \mathrm{ka} \mathrm{cal}$. BP underlines a common climate forcing leading to high frequency wiggles in terrigenous discharge around the Alps. Since $2.2 \mathrm{ka}$ cal. BP, both records exhibit discrepancies that could be explained by different responses to human impact on erosion.

\section{Conclusion}

Lake Bourget high resolution geochemical record brings new insights upon both the evolution of soil dynamics and paleohydrology at a regional scale in NW Alps. We show that most of the Holocene was a period of reduced erosion fluxes due to a combination of dry climate and extensive soil development precluding intense erosion where remaining glaciers did not take place. The first impacts of human activities, during the Bronze Age, resulted more into a change in erosion patterns than a marked increase in regional erosion fluxes. In this our record differs from local studies led in small-scale high elevated catchments areas. It is nevertheless likely that at the end of the Iron Age and more probably during the Antiquity, the intensity of human impact was such that it resulted in a regional increase of terrigenous fluxes. However, the subsequent periods were dominated by far by the activation of glacier systems in the Mont Blanc Massif that culminated during the Little Ice Age which is the longest and most intense period of erosion over the whole Holocene.

Regarding paleohydrology, our results exhibit a pattern in agreement with previous lower resolution studies, both in the long-term trend and at a higher time resolution. In particular, we illustrate that the Holocene has been marked by dry conditions in the Alps until ca. $5.5 \mathrm{ka}$ cal. BP and the onset of the so-called Neoglacial. Since then a trend was onset toward more humid conditions that culminated during the Little Ice Age. This suggests that current climatic conditions, marked by low hydrological activity, are out-of-trend compared to the Holocene climate evolution and could be attributed to current global warming.

\section{Acknowledgements}

XRF core-scanner measurements have been performed at the University of Bremen. LDB01-I was measured thanks to the EU-Project "Paleostudies" (contract-no.: HPRI-2001-00124). Drs. Frank Lamy 
and Holger Kuhlmann are acknowledged for having managed this project. Authors also wish to thank Heike Pfletschinger (University Bremen - ODP Core Repository) for her help in using the corescanner. Dr. Thierry Winiarski (ENTPE-Lyon) is acknowledged for its support for field logistics.

This study is part of the research programs Aphrodyte II, funded by the interdisciplinary program Eclipse of the French National Institute of Universe Sciences (INSU) and Pygmalion founded by the French National Research Agency (ANR BLAN07-2_204489). All ${ }^{14} \mathrm{C}$ ages referred as "SacA" were measured in Saclay LMC14 laboratory in the framework of the national program "Artemis". The authors express their grateful thanks to the Saclay laboratory team, in particular to Jean-Pascal Dumoulin, as well as to Tomas Goslar from Poznan Radioacarbon Laboratory for constant help in the management of ${ }^{14} \mathrm{C}$ samples and results.

\section{References}

Arnaud, F., 2005. Discriminating the fingerprints of bio-induced and detrital sedimentary processes in particle size distribution spectra of hard water lake sediments. Journ. of Paleolim. 34-4, 519-526.

Arnaud, F., Revel-Rolland, M., Chapron, E., Desmet, M., Tribovillard, N., 2005. 7200 years of Rhône river flooding activity recorded in Lake Le Bourget: A high resolution sediment record of NW Alps hydrology. Holocene 15, 420-428.

Arnaud, F., Revel-Rolland, M., Bosch, D., Winiarski, T., Chapron, E., Desmet, M., Tribovillard, N., Givelet, N., 2004. A reliable 300 years-long history of lead contamination in Northern French Alps from distant lake sediment records. Journ. of Env. Mon. 6, 448-456.

Blaauw, M., 2010. Methods and code for ,classical ${ }^{l e}$ age-modelling of radiocarbon sequences. Quat. Geochronology 5, 512-518.

Bravard, J.-P., 1987. Le Rhône, Du Léman à Lyon. Editions La Manufacture. Lyon.

Carrier, N. and Mouthon, F., 2010. Paysans des Alpes - Les communautés montagnardes au Moyen Âge. Presses universitaires de Rennes. 420 pp. ISBN 978-2-7535-1091-3.

Chapron, E., 1999. Contrôle climatique et sismo-tectonique de la sédimentation lacustre dans l“AvantPays Alpin (Lac du Bourget) durant le Quaternaire récent. Géologie Alpine, mémoire H.S. nº 30.

Chapron, E., Beck, C., Pourchet, M \& Deconinck, J.-F., 1999. 1822 earthquake-triggered homogenite in Lake Bourget (NW Alps). Terra Nova 11, 86-92. 
Chapron, E., Desmet, M., De Putter, T., Loutre, M.-F., Beck, C., Deconinck, J.-F., 2002. Climatic variability in the northwestern Alps, France, as evidenced by 600 years of terrigenous sedimentation in Lake Bourget. The Holocene 12, 177-185.

Chapron, E., Arnaud, F., Noël, H., Revel-Rolland, M., Desmet, M., Perdereau, L., 2005. Rhone River flood deposits in Lake Le Bourget: a proxy for Holocene environmental changes in the NW Alps, France. Boreas, 34, 404-416.

David, F., 2010. An example of the consequences of human activities on the evolution of subalpine landscapes. C. R. Palevol 9, 229-235

David F., 1993. Extension tardiglaciaire des pins dans les Alpes du Nord. CRAS série II, 317, $123-$ 129.

Dearing, J. A. \& Jones, R. T., 2003. Coupling temporal and spatial dimensions of global sediment flux through lake and marine sediment records. Global and Planetary Change 39, 147-168.

Debret, M., Chapron, E., Desmet, M., Rolland-Revel, M., Magand, O., Trentesaux, A., BoutRoumazeille, V., Nomade, J., Arnaud, F., 2010. North western Alps Holocene paleohydrology recorded by flooding activity in Lake Le Bourget, France. Quatern. Sci. Rev. 29, 2185-2200.

Deline, P., Orombelli, G., 2005. Glacier fluctuations in the western Alps during the Neoglacial, as indicated by the Miage morainic amphitheatre (Mont Blanc massif, Italy). Boreas 34, 456-467.

Disnar, J.-R., Jacob, J., Morched-Issa, M., Arnaud, F., Lottier, N., 2008. Assessment of peat quality by molecular and bulk geochemical analysis; application to the Holocene record of the Chautagne marsh (Haute Savoie, France). Chemical Geology, 254, 101-112.

Giguet-Covex, C., Arnaud, F., Poulenard, J., Enters, D., Reyss, J.-L., Vidal, O., 2010. Multi-proxy reconstruction of trophic state and hypolimnetic anoxia in a large hard-water lake (Lake Bourget, French Alps) over the past 140 years. Journal of Palaeolimnology 43, 171-190.

Giguet-Covex C., Arnaud, F., Poulenard, J., Disnar, J.R., Delhon, C., Francus, P., David, F., Enters, D., Rey, P.-J., Delannoy, J.-J., 2011. Changes of erosion patterns during the Holocene in a currently treeless subalpine catchment inferred from lake sediment geochemistry (Lake Anterne, $2063 \mathrm{~m}$ asl, NW French Alps). The Holocene 21, 651-665 
Giguet-Covex C., Arnaud, F., Enters, D., Poulenard, J., Millet, L., Francus, P., David, F., Rey, P.-J., Wilhelm, B., Delannoy, J.-J., 2012. Frequency and intensity of high altitude floods over the last $3.5 \mathrm{ka}$ in NW European Alps. Quaternary Research 77, 12-22

Holzhauser, H., Magny, M., Zumbühl, H.J., 2005. Glacier and lake-level variations in west-central Europe over the last 3500 years. The Holocene 15, 789-801.

Jacob, J., Disnar, J.-R., Arnaud, F., Chapron, E., Debret, M., Lallier-Vergès, E., Desmet, M., RevelRolland, M., 2008. Millet cultivation history in the French Alps as evidenced by a sedimentary molecule. Journal of Archaeological Science, 35, 814-820.

Jacob, J., Disnar, J.-R., Arnaud, F., Gauthier, E., Billaud, Y., Bardoux, G., 2009. Agriculture and soil erosion during the Bronze Age around Lake Le Bourget (French Alps). The Holocene 19, 241-249

Jacobsen, S. B. and G. J. Wasserburg, 1980. "Sm-Nd isotopic evolution of chondrites." Earth and Planetary Science Letters, 50, 139-155.

Joerin, U.E., Stocker, T.F., Schlüchter, C., 2006. Multicentury glacier fluctuations in the Swiss Alps during the Holocene. The Holocene 16, 697-704.

Joerin, U.E., Nicolussi, K., Fischer, A., Stocker, T.F., Schlüchter, C., 2008. Holocene optimum events inferred from subglacial sediments at Tschierva Glacier, Eastern Swiss Alps. Quaternary Science Reviews 27, 337-350.

Jung, S., Arnaud, F., Bonté, P., Chebbo, G., Lorgeoux, C., Winiarski, T., Tassin, B., 2008. Temporal evolution of urban wet weather pollution: analysis of PCB and PAH in sediment cores from Lake Bourget, France. Water Science \& Technology 57, 1503-1510.

Ledoux, G., Lajeunesse, P., Chapron, E., St Onge, G., 2010. Multibeam bathymetry investigation of mass movements in Lake Le Bourget (NW Alps, France) using a portable platform. In Submarine mass movements and their consequences. Advances in natural and technological hazrds research 28 II, 423-434.

Magny, M. and Richard, H., 1985. Contribution à l'histoire holocène du Lac du Bourget : recherches sédimentologiques et palynologiques sur le site de Conjux-La Chatière (Savoie, France). Revue de Paléobiologie 4, 253-277. 
Magny, M., Bégeot, C., Guiot, J., Peyron, O., 2003. Contrasting patterns of hydrological changes in Europe in response to Holocene climate cooling phases. Quaternary Science Reviews 22, 1589-1596

Magny, M., Leuzinger, U., Bortenschlager, S., Haas, J. N., 2006. Tripartite climate reversal in Central Europe 5600-5300 years ago. Quaternary Research 65, 3 - 19

Magny, M., Peyron, O., Gauthier, E., Rouèche, Y., Bordon, A., Billaud, Y., Chapron, E., Marguet, A., Pétrequin, P., Vannière, B., 2009. Quantitative reconstruction of climatic variations during the Bronze and early Iron ages based on pollen and lake-level data in the NW Alps, France. Quaternary International, 200, 102-110

Magny, M., Arnaud, F., Holzhauser, H., Chapron, E., Desmet, M., Leroux, A., Millet, L., Vannière, B., 2010. Solar and site-sensitivity imprints on palaeohydrological records for the last millennium in west-central Europe Quaternay research 73, 173-179

Magny, M., Bossuet, G., Ruffaldi P., Leroux A., Mouthon J., 2011. Orbital imprint on Holocene palaeohydrological variations in west-central Europe as reflected by lake level changes at Cerin (Jura Mountains, eastern France). Journal of Quaternary Science, 26, 171-177.

Magny M., Arnaud F., Billaud, Y., Marguet, A., In press. Lake-level fluctuations at Lake Bourget (eastern France) around 4500-3500 cal BP and their palaeoclimatic and archaeological implications. Journal of Quaternary Science

Marguet, A., 2000, Elaboration de la carte archéologique des gisements du Lac du Bourget in Direction de learchitecture et du patrimoine in Sous-direction des recherches archéologiques subaquatiques et sous-marines: Bilan Scientifique 2000. Ministère de la culture et de la communication. Paris. pp. $117-137$.

Mayewski, P.A., Rohling, E.E., Stager, J.C., Karlén, W., Maasch, K.A., Meeker, L.D., Meyerson, E.A., Gasse, F., van Kreveld, S., Holmgren, K., Lee-Thorp, J., Rosqvist, G., Rack, F., Staubwasser, M., Schneider, R.R. \& Steig, E.J., 2004. Holocene climate variability. Quaternary Research, 62, 243255.

Millet, L., Giguet-Covex, C., Verneaux, V., Druart, J-C., Adatte, T., Arnaud, F., 2010. Reconstruction of the recent history of a large deep prealpine lake (Lake Bourget, France) using subfossil chironomids, diatoms, and organic matter analysis: towards the definition of a lake-specific reference state. Journal of Palaeolimnology, 44, 963-978 
Mourier, B., Poulenard, J., Carcaillet, C., Williamson, D., 2010. Soil evolution and subalpine ecosystem changes in the French Alps inferred from geochemical analysis of lacustrine sediments. Journal of paleolimnology 44, 571-587.

Nesbitt, H. W. \& Young, G. M., 1982. Early proterozoic climates and plate motion inferred from major element chemistry of lutites. Nature 299, 715-717.

Nicoud, G., Monjuvent, G., Maillet-Guy, G., 1987, Contrôle du comblement quaternaire des vallées alpines du Nord par la dynamique lacustre. Géologie Alpine, Mém. HS 113, 457-468.

Piccarreta, M., Caldara, M., Capolongo, D., Boenzi, F., 2011. Holocene geomorphic activity related to climatic change and human impact in Basilicata, Southern Italy. Geomorphology, 128, 137-147.

Pin, C. and Santos Zalduegui, J. F., 1997. "Sequential separation of light rare-earth elements, thorium and uranium by miniaturized extraction chromatography: Application to isotopic analyses of silicate rocks." Analytica Chimica Acta, 339, 79-89.

R Development Core Team (2011). R: A language and environment for statistical computing. R Foundation for Statistical Computing, Vienna, Austria. ISBN 3-900051-07-0, URL http://www.Rproject.org/.

Reimer, P.J., Baillie, M.G.L., Bard, E., Bayliss, A., Beck, J.W., Blackwell, P.G., Bronk Ramsey, C., Buck, C.E., Burr, G.S., Edwards, R.L., Friedrich, M., Grootes, P.M., Guilderson, T.P., Hajdas, I., Heaton, T.J., Hogg, A.G., Hughen, K.A., Kaiser, K.F., Kromer, B., McCormac, F.G., Manning, S.W., Reimer, R.W., Richards, D.A., Southon, J.R., Talamo, S., Turney, C.S.M., van der Plicht, J., Weyhenmeyer, C.E., 2009. IntCa109 and Marine09 radiocarbon age calibration curves, 0-50,000 years cal BP. Radiocarbon, 51, 1111-1150.

Revel-Rolland, M., Arnaud, F., Chapron, E., Desmet, M., Givelet, N., Alibert, C., McCulloch, M. 2005. Sr and Nd isotope as a tracer of sources of clastic material, in the Bourget lake sediment (NW Alps, France) during the Little Ice Age. Chemical Geology, 224, 183-200.

Revillon,, S. and Hureau-Mazaudier, D., 2009. Improvements in Digestion Protocols for Trace Element and Isotope Determinations in Stream and Lake Sediment Reference Materials (JSd-1, JSd-2, JSd-3, JLk-1 and LKSD-1). Geostandards and Geoanalytical Research, 33, 397-413. 
Schmidt, R., Koinig, K.A., Thompson, R., Kamenik, C. 2002. A multi-proxy core study of the last 7000 years of climate and alpine land-use impacts on an Austrian mountain lake (Unterer Landschitzsee, Nieder Tauern). Palaeogeography, Palaeoclimatology, Palaeoecology 187, 101-20.

Trentesaux, A., Recourt, P., Bout-Roumazeilles, V., Tribovillard, N., 2001. Carbonate grain sizer distribution in hemipelagic sediment from a laser particle sizer. J. Sediment. Res. Sec. A: Sediment. Petrol. Process, 71, 858-862.

van Rensbergen, P., De Batist, M., Beck, C., Chapron, E., 1999: High-resolution seismic stratigraphy of glacial to interglacial fill of a deep glacigenic lake: Lake Bourget, North Western Alps, France. Sedimentary Geology 128, 99-129.

van der Knaap, W.O., van Leeuwen, J. F. N., Finsinger, W., Gobet, E., Pini, R., Schweizer, A., Valsecchi, V., Ammann, B., 2005. Migration and population expansion of Abies, Fagus, Picea, and Quercus since 15000 years in and across the Alps, based on pollen-percentage threshold values. Quaternary Science Reviews, 24, 645-680

von Grafenstein, U., Erlenkeuser, H., Brauer, A., Jouzel, J., Johnsen, S. J., 1999. A Mid-European Decadal Isotope-Climate Record from 15,500 to 5000 Years B.P. Science, 284, 1654-1657.

Wessels, M., 1998. Natural environmental changes indicated by Late Glacial and Holocene sediments from Lake Constance, Germany. Palaeogeography, Palaeoclimatology, Palaeoecology, 140, 421-432. 
Fig. 1. A) Location of Lake Bourget in Western Europe together with Lakes Constance (Co) and Accesa (Ac) that are discussed in the text. The white square is a zoom on the location of lake Bourget. Lakes Cerin, Annecy and Anterne that are discussed in the text, are also displayed. The grey areas represent the Upper Rhône catchment area $\left(4000 \mathrm{~km}^{2}\right)$, upstream Lake Bourget (excluding Lake Léman catchment area, cf. text): in light grey are carbonatedominated areas (Jura and Prealps); dark grey areas represent crystalline massifs (Mt Blanc). B) Location of studied sediment cores in Lake Bourget northern basin, together with seismic profiles crossing core locations.

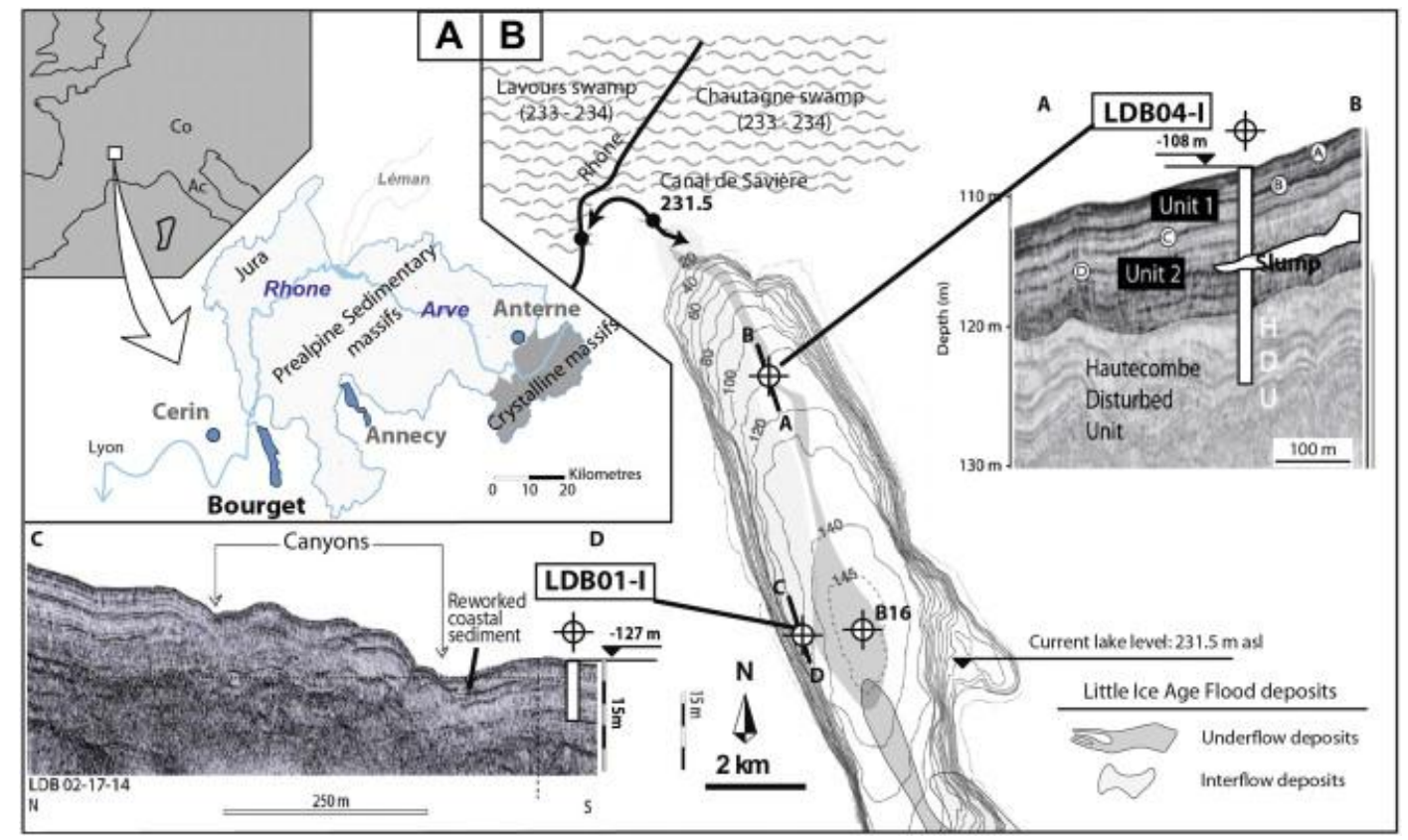



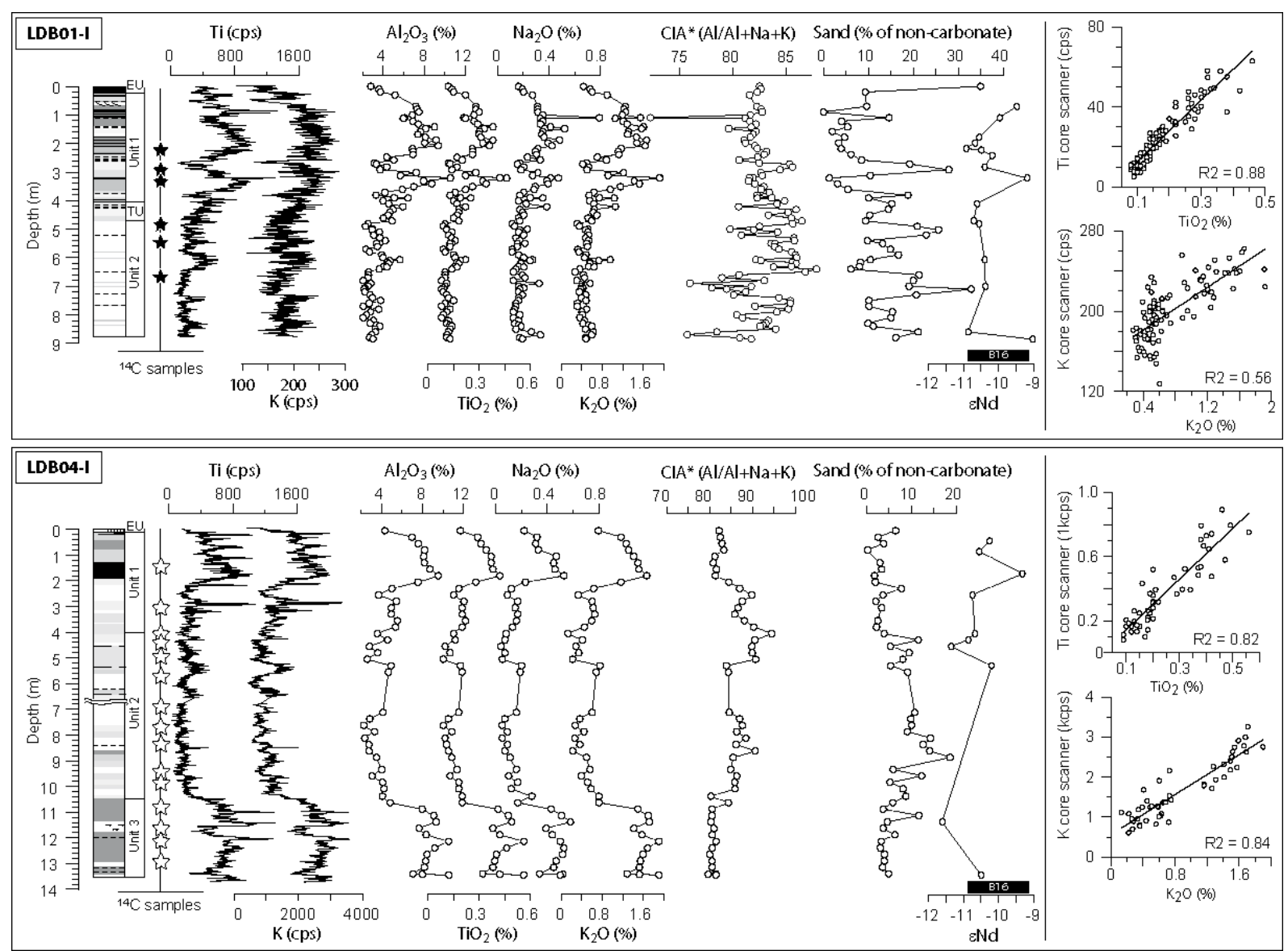

Fig. 2. Geochemical proxies measured both by core scanning and punctual XRF and non-carbonated sand contents for core LDB01-I and LDB04-I. On the right side are the bi-plots used to calibrate XRF core scanner data using punctual measurement. Note that bad correlation of K in LDB01-I led not to use the $\mathrm{K} / \mathrm{Ti}$ ratio for this core. 


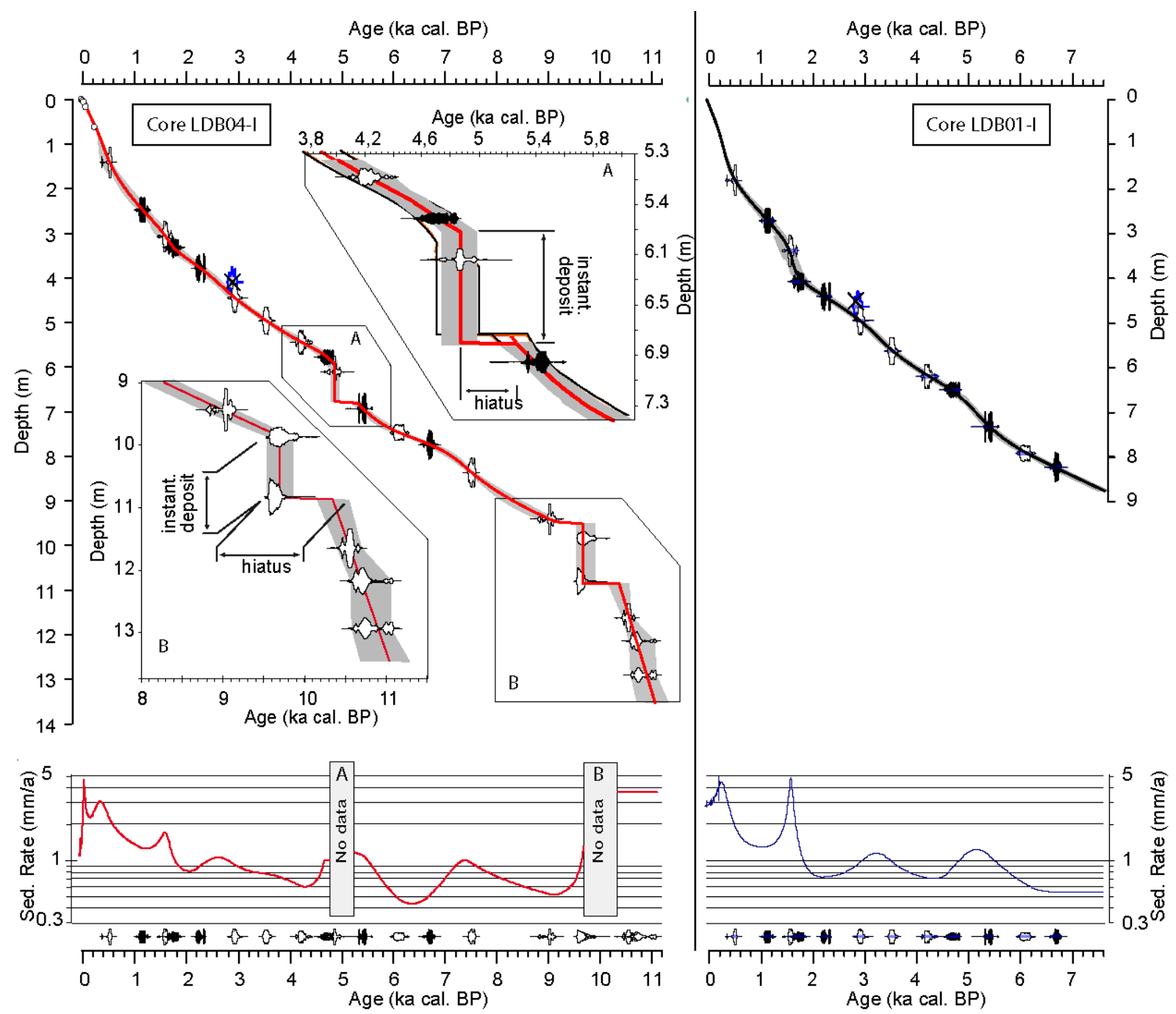

Fig. 3. Age-modelling of both cores LDB01-I and LDB04-I. Black symbols represent calibration probability plots of samples taken on LDB01-I, whereas white ones were taken on LDB04-I. To increase the representativeness of age models, when possible, samples from one core were reported in the age-model of the other one through the correlation of high resolution geochemical signals. Agemodels, as well as sedimentation rates, were computed using CLAM. For LDB04-I two sections received a particular attention to take into account both hiatuses and instantaneous deposits which were previously identified thanks to seismic imagery. 

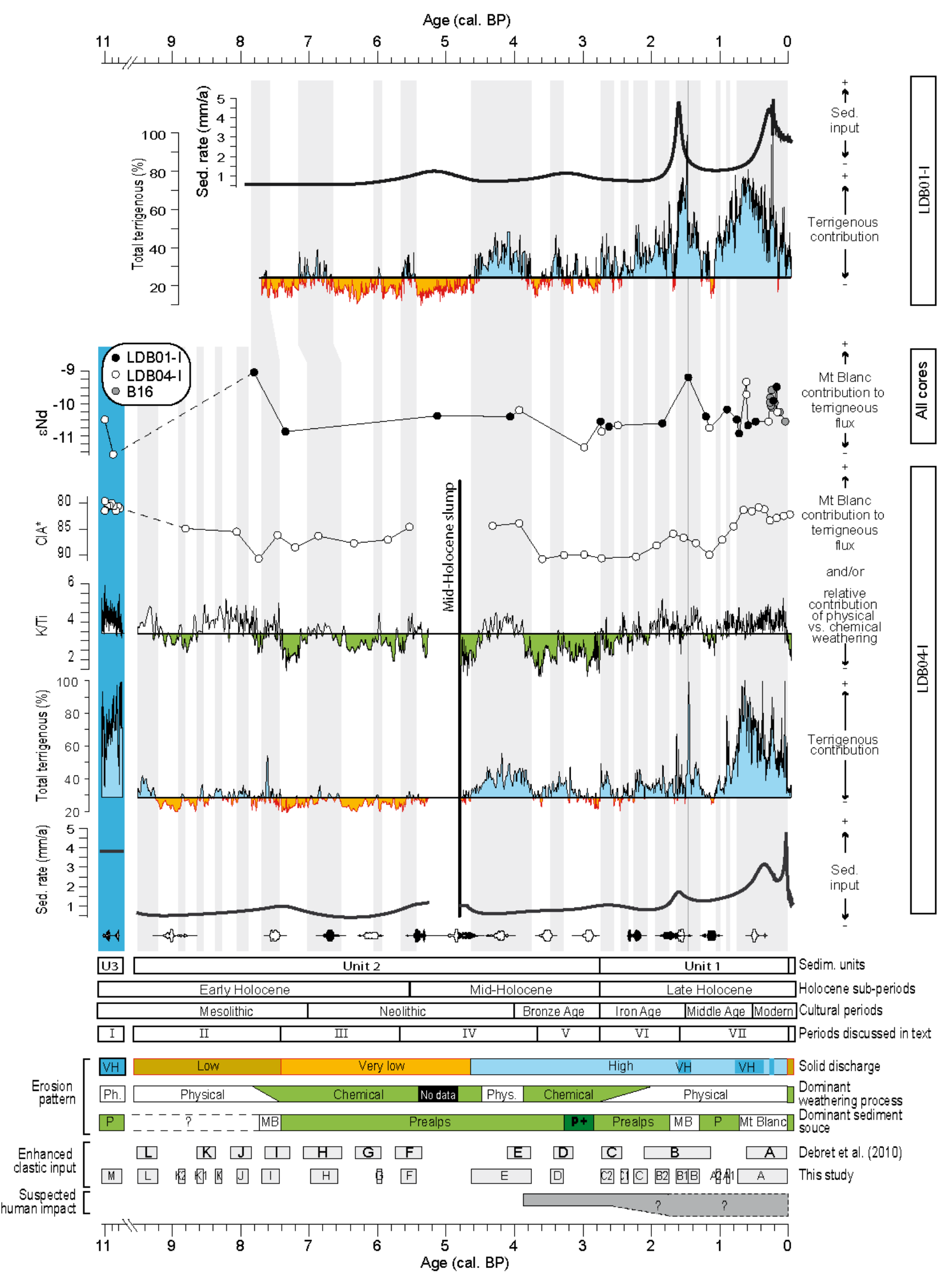

Fig. 4. Geochemical proxies plotted against time together with their interpretation in terms erosion intensity $(\mathrm{VH}=$ very high), pattern (chemical vs. physical) and source (prealps $=\mathrm{P}$ vs. Mont Blanc massif $=$ MB). Phases of enhanced detrital input generally fit with previously published one by Debret al. (2010), however the higher resolution of the geochemical signal led to propose a refined nomenclature of them. Human impact is suspected since the Bronze Age due a preponderance of prealpine, highly weathered material. 


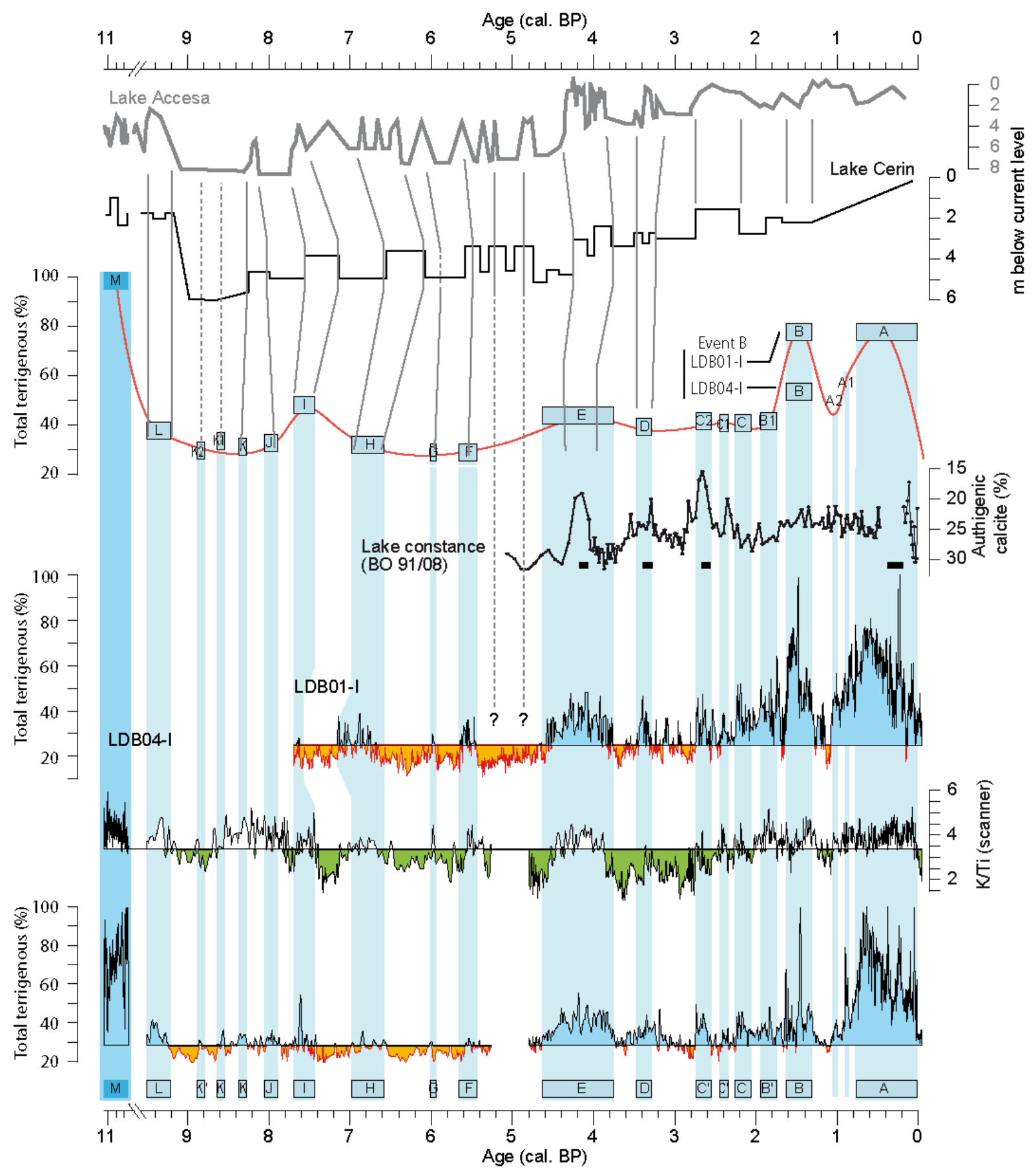

Fig. 5. Main Lake Bourget geochemical signals compared with regional reconstructions of hydrological conditions (Lake Accesa and Cerin: Magny et al., 2011; Lake Constance: Wessels, 1998) 
Table 1. Chronostratigraphic information incorporated into CLAM to generate age-depth models. All data were previously published in *Chapron et al., 1999; ${ }^{* *}$ Debret et al., 2010; ${ }^{* * *}$ Giguet-Covex et al., 2010; ${ }^{* * *}$ Arnaud et al., 2005 . Bold Depth values refer to the position of the sample in the core where it has been sampled. Normal depth values refer the correlated position of the same sample in the other core.

\begin{tabular}{|c|c|c|c|c|c|c|c|c|}
\hline $\begin{array}{l}\text { Stratigraphic } \\
\text { mark or }{ }^{14} \mathrm{C} \text { lab. } \\
\text { code }\end{array}$ & $\begin{array}{l}\text { Sampled } \\
\text { in core }\end{array}$ & $\begin{array}{l}\text { Depth in } \\
\text { LDB01 } \\
(\mathrm{cm})\end{array}$ & $\begin{array}{l}\text { Depth in } \\
\text { LDB04 } \\
(\mathrm{cm})\end{array}$ & $\begin{array}{l}\text { Age } \\
\text { (cal. BP) }\end{array}$ & $\begin{array}{l}{ }^{14} \mathrm{C} \text { age } \\
\text { (BP) }\end{array}$ & $\begin{array}{l}\text { Thickness } \\
(\mathrm{cm})\end{array}$ & $\begin{array}{l}\text { Cal. min. } \\
\text { (cal. BP) }\end{array}$ & $\begin{array}{l}\text { Cal. max. } \\
\text { (cal. BP) }\end{array}$ \\
\hline Homogenite $^{*}$ & LDB-01 & 53 & - & 128 & - & 7.5 & - & - \\
\hline Chernobyl ${ }^{t *}$ & LDB-04 & - & 2 & -36 & - & 1 & - & - \\
\hline At. Bomb tests ${ }^{*}$ & LDB-04 & - & 5 & -15 & - & 1 & - & - \\
\hline Top Eut. Unit ${ }^{\text {t*t }}$ & LDB-04 & - & 3 & 7 & - & 1 & - & - \\
\hline Flood $(1905)^{* *}$ & LDB-04 & - & 19 & 45 & - & 5 & - & - \\
\hline Flood $(1733)^{*}$ & Both & 85.5 & 64 & 217 & - & 1 & - & - \\
\hline Poz-710*tz & LDB-01 & 271 & 250.5 & - & $1200 \pm 30$ & 1 & 1055 & 1180 \\
\hline Poz-718 & LDB-01 & 407 & 335 & - & $1800 \pm 45$ & 1 & 1610 & 1830 \\
\hline Poz-716 & LDB-01 & 4405 & 381 & - & $2250 \pm 30$ & 1 & 2160 & 2340 \\
\hline Poz- $717^{\star \star * t}$ & LDB-01 & 619 & 548 & - & $3820 \pm 30$ & 1 & 4090 & 4300 \\
\hline Poz-715 & LDB-01 & 6675 & 614 & - & $4280 \pm 40$ & 1 & 4815 & 4965 \\
\hline Poz- $721^{\text {**t }}$ & LDB-01 & 791 & 750 & - & $5310 \pm 40$ & 1 & 5990 & 6205 \\
\hline Poz-13986" & LDB-04 & 180.5 & 144 & - & $435 \pm 30$ & 1 & 460 & 530 \\
\hline Poz-13983*t & LDB-04 & 338 & 310 & - & $1665 \pm 30$ & 1 & 1515 & 1630 \\
\hline SACA4834 ${ }^{* t}$ & LDB-04 & 463 & 412.8 & - & $2770 \pm 30$ & 1 & 2790 & 2930 \\
\hline Poz-13984 & LDB-04 & 494 & 448 & - & $2815 \pm 30$ & 1 & 2850 & 3000 \\
\hline Poz-13985 & LDB-04 & 562.5 & 499 & - & $3300 \pm 30$ & 1 & 3450 & 3590 \\
\hline Poz-10562 & LDB-04 & 649 & 581 & - & $4160 \pm 35$ & 1 & 4580 & 4830 \\
\hline Poz-14033"t & LDB-04 & - & 696 & - & $4640 \pm 35$ & 1 & 5305 & 5465 \\
\hline Poz-14032 & LDB-04 & 822 & 777 & - & $5870 \pm 40$ & 1 & 6620 & 6790 \\
\hline Poz-10563 & LDB-04 & - & 840 & - & $6610 \pm 40$ & 1 & 7435 & 7565 \\
\hline Poz-13987 & LDB-04 & - & 944 & - & $8080 \pm 40$ & 1 & 8780 & 9130 \\
\hline SacA4836 ${ }^{* t}$ & LDB-04 & - & 1083.5 & - & $8655 \pm 45$ & 1 & 9535 & 9700 \\
\hline SacA4835 ${ }^{* t}$ & LDB-04 & - & 9875 & - & $8720 \pm 50$ & 1 & 9550 & 9870 \\
\hline SacA4837" & LDB-04 & - & 1165.5 & - & $9320 \pm 35$ & 1 & 10,420 & 10,600 \\
\hline Poz-10565 & LDB-04 & - & 1218 & - & $9450 \pm 50$ & 1 & 10,560 & 11,060 \\
\hline Poz-10566" & LDB-04 & - & 1294 & - & $9490 \pm 50$ & 1 & 10,590 & 11,072 \\
\hline
\end{tabular}

